\title{
The Economic Implications of Compensation Package to a Business Process Outsourcing in Bacolod City
}

\author{
Luneta Fe S. David ${ }^{1}$ and Anabelle S. Palic ${ }^{2}$ \\ ${ }^{1} \mathrm{KL}$ Seven Accounting Services, Inc., Bacolod City, Philippines \\ ${ }^{2}$ University of Negros Occidental-Recoletos, Bacolod City, Philippines
}

\begin{tabular}{l} 
Article history \\
Submitted: 23 October 2020 \\
Revised: 4 November 2020 \\
Accepted: 10 November 2020 \\
\hline Keywords \\
Business Administration \\
Economic Implications \\
Compensation Package \\
Business Process Outsourcing \\
Descriptive \\
Bacolod City
\end{tabular}

Article history

Submitted: 23 October 2020

Introduction. As one of the most comprehensive compensation tools for motivating employees, compensation package plans are forms of payment in an organization's compensation practices associated with performance (Hollenbeck, Gerhart \& Wright, 2017). It is generally one of the organization's highest costs (Mckinney, 2016). According to the U.S. Bureau of Labor Statistics (BLS), $69.6 \%$ of a business' employee compensation expenses comprise the salaries and wages. While some costs are controllable, most employers must bear several salary-related costs beyond the base salary (Keegan, 2020). By far, there has never been any attempt to investigate the economic implications of the compensation package in terms of savings on expenditures. Hence, this study primarily intends to determine the economic implications of the compensation package to a business process outsourcing (BPO) in Bacolod City in terms of savings on expenditures. Likewise, it examines the strengths, weaknesses, threats, and opportunities of the company.

Methods. The study utilized the descriptive research design. The respondents were the 40 employees of the BPO company, consisting of 9 supervisors and 31 rank and file. The research study used secondary data. The documents and reports, such as company financial statements, accounting software, payroll reports, government remittances files, and others, were accessed, gathered, and analyzed. Additionally, a SWOT checklist was used to identify the company's strengths, weaknesses, opportunities, and threats. To analyze the secondary data, the percentage distribution and ratio were used. In contrast, for the SWOT analysis, the frequency count and percentage distribution were applied as statistical tools.

Results. The findings showed that significant savings would be created for the salaries since the hiring and training costs were avoided. The employee benefits connected to the cost of the newly hired employees will produce savings as well. On the other hand, an additional cost will be created by the enhanced paid time off, meal allowance, and medical. Enhanced company rewards will also increase because the employees are expected to work and perform better. Based on the results of the study, some of the expenditures will increase because of the perks added to the package. However, the enhancement of the company's compensation package will generate savings because of the hiring and training costs eliminated from the expenditures. Based on the SWOT checklist, the company's compensation package is competitive within Bacolod City. It provides the company with an edge against other accounting outsourcing companies. However, the annual increase in salary is not satisfactory. The compensation package does not secure the employees' future and does not assure employee tenure. The rewards push them towards personal achievement rather than the achievement of company goals. Ninety percent of the company's population is females; thus, the probability of availing maternity leave is high. On Opportunities, the possibility of the company's expansion is high since the cost of labor in Canada is costlier than in the Philippines. The need for accounting outsourcing is prevalent. Thus, it will provide more clients for the organization. The threats of the company involved the increasing inflation rate and cost of the accounting software. Additionally, some clients offer exciting salary rates to home-based accountants. Lastly, the office building has no generator set to back up the company's operation from power interruption. 
Conclusion. The findings of the study indicated that the proposed enhanced compensation package has significant economic implications and benefits to the business. This will decrease the total expenditures because the hiring cost will be eliminated due to employee retention. Schemes such as merit increase based on employee performance will add to their income as employees. Also, providing them with a medical allowance and giving them a loyalty award will positively impact them. They tend to be more motivated and inspired to perform well, and thus, redound to savings for the company. Moreover, better performance from motivated employees brings increased company revenues.

Practical Value of the Paper. The study's findings provide baseline information to the management in designing an enhanced compensation package to improve the employees' morale and performance and provide savings for the company. Moreover, the study meaningfully contributes to the limited existing literature on the economic implications of the compensation package.

\section{References}

Aron, R., \& Singh, J. (2003). IT enabled strategic outsourcing: Knowledge intensive firms, information work and the extended organizational form. Knowledge@ Wharton, The Wharton School, University of Pennsylvania.

Falola, H. O., Ibidunni, O. S., \& Olokundun, A. M. (2014). Incentives packages and employees' attitudes to work: a study of selected government parastatals in Ogun State, South-West, Nigeria. International Journal of Research in Business and Social Science, 3(1), 63-74.

Hollenbeck, J., Gerhart, B. \& Wright, P. (2017). Fundamentals of Human Resource and Management of Services 2nd Ed. McGraw Hill, 232-235. Retrieved from https://www.mheducation.com/highered/product/fundamentals human-resource-management-noe-hollenbeck/M9781260079173.html.

Jiang, B., \& Qureshi, A. (2006). Research on outsourcing results: current literature and future opportunities. Management Decision.

Keegan, M. (2020). Salary Related Costs for Employers. Retrieved from https://smallbusiness.chron.com/salaryrelated-costs-employers-12037.html.

Leavy, B. (2004). Outsourcing strategies: opportunities and risks. Strategy \& Leadership.

Mckinney, P. (2016). What Is Employee Compensation? - Definition \& Concept. (2016, January 26). Retrieved from https://study.com/academy/lesson/what-is-employee-compensation-definition-lesson-quiz.html.

Mehta, A., Armenakis, A., Mehta, N., \& Irani, F. (2006). Challenges and opportunities of business process outsourcing in India. Journal of Labor Research, 27(3), 323-338.

\section{Correspondence:}

Luneta Fe S. David [shearnhet@gmail.com]

http://orcid.org/0000-0001-5548-2682 